\title{
CONTRACT MODIFICATION: AN ECONOMIC ANALYSIS OF THE HOLD-UP GAME
}

\author{
Daniel A. Graham* and Ellen R. Peirce $\dagger$ \\ I \\ INTRODUCTION
}

The very foundation of our contract law is based upon the premise of the bilateral voluntary exchange. In a market economy, such exchanges involve a process in which the parties bargain voluntarily, each striving to maximize his own economic advantage on terms that are acceptable to the other party. ${ }^{1}$ The presumption is that this process yields a "Pareto improvement" in which at least one party is better off and neither party is worse off than would have been the case without the exchange. ${ }^{2}$ The same logic suggests that if the parties to a contract should subsequently wish to modify it due to some change in economic circumstances, unforeseen circumstances, or simply a change of mind, ${ }^{3}$ then modifications freely entered into by both parties should yield further Pareto improvement and should be enforceable. ${ }^{4}$

However, a problem arises when one party to a contract agrees to a proposed modification either because of expected dire consequences should that party not agree to the modification or because the available remedies for breach by the other party are inadequate to deter breach by the other party. ${ }^{5}$ This point is emphasized by White and Summers, who note that not all

Copyright (c) 1989 by Law and Contemporary Problems

* Professor of Economics, Duke University, Durham, North Carolina.

$\dagger$ Professor of Economics, University of North Carolina, Chapel Hill, North Carolina.

1. As Adam Smith stated, man "must interest [others'] self-love in his favour, and show them that it is for their own advantage to do for him what he requires of them." A. SMITH, AN INQUIRY into the Nature and Causes of the Wealth of Nations 19 (1776). See also E. Farnsworth, Contracts $\S 1.2$, at 7 (1982).

2. E. FARNSWORTH, supra note 1 .

3. See J. White \& R. Summers, Uniform Commercial Code $\S 1-6$, at 54 (3d ed. 1988).

4. See Fuller \& Perdue, The Reliance Interest in Contract Damages, 46 YALE L.J. 52, 61 (1936); Hartzler, The Business and Economic Functions of the Law of Contract Damages, 6 AM. Bus. L.J. 387,392 (1968); Macneil, Contracts: Adjustment of Long-Term Economic Relations Under Classical, Neoclassical and Relational Contract Law, 72 Nw. U.L. REv. 854, 862 (1978).

5. As noted by Judge Posner in a recent decision:

It undermines the institution of contract to allow a contract party to use the threat of breach to get the contract modified in his favor not because anything has happened to require modification in the mutual interest of the parties but simply because the other party, unless he knuckles under to the threat, will incur costs for which he will have no adequate legal remedy. If contractual protections are illusory, people will be reluctant to make contracts.

Selmer Co. v. Blakeslee-Midwest Co., 704 F.2d 924, 927 (7th Cir. 1983). See also Hillman, Policing Contract Modifications under the UCC: Good Faith and the Doctrine of Economic Duress, 64 Iowa L. REv. 849, 880 n.152 (1979); Macneil, supra note 4. 
contract modifiers are honest. 6 "Some are extortionists, some are profiteers, and some are chiselers." 7 Similarly, Corbin coined the suggestive term "holdup game" in discussing the rationale for not enforcing a contract modification involving extortion. ${ }^{8}$

The law recognizes that some modifications should be upheld because they are entered into freely and some should be deemed unenforceable because they derive from coercion or duress. ${ }^{9}$ The problem is that there is a very fine line between free but hard bargaining on the one hand and coercion or duress on the other. The expanding use of duress as a justification for a court's refusal to enforce contract modifications ${ }^{10}$ has made it progressively more difficult for parties vigorously engaged in bargaining over contract modifications to know the current location of the fine line. ${ }^{11}$

A number of commentators have analyzed this problem from the vantage point of policing the bargaining process, ${ }^{12}$ while others have analyzed it in terms of the fairness of the resulting exchange. ${ }^{13}$ This article examines the law of contract modification from a purely economic perspective. It offers an economic explanation as to why the law enforces certain contract modifications while refusing to enforce others. The analysis focuses on the economic interpretation of the legal term "economic duress" (the hold-up game), and on each party's objective circumstances at the time of the proposed modification.

This economic analysis of the hold-up game posits the following:

6. See J. White \& R. Summers, supra note 3.

7. Id.

8. Corbin uses this phrase to refer to the situation in which a party to a contract, through the use of economic duress, forces the other party to agree to a contract modification. 1A A. Conbin, Corbin on Contracts $\$ 171$, at 105 (1963).

9. See, e.g., Watkins \& Son v. Carrig, 91 N.H. 459, 21 A.2d 591 (1941) (modification upheld where a party agreed to excavate a cellar at a fixed price but unexpectedly encountered rock and refused to proceed without an agreement by the owner to pay extra). This case was based on an exception to the pre-existing duty rule, which is noted in the Restatement (Second) of Contracts $\S 89$ (1979): Modifications to contracts should be upheld even if not supported by consideration if the modification is fair and equitable in view of the circumstances. See infra Part IV. But see Ruffin v. Mercury Record Productions, Inc., 513 F.2d 222 (6th Cir. 1975), cert. denied, 423 U.S. 914 (1975) (oral promise to supplement salary made by employer to employee subsequent to employment contract not enforceable for failure of consideration).

10. For a discussion of the expanding use of duress as a justification for denying enforcement of a modification see E. FarNSWORTH, supra note 1 , § 4.17, at 259-64.

11. As one commentator notes, as courts continue to expand the concept of duress, it has become increasingly difficult to "define with precision the proper limits of bargaining." $I d$. $§ 4.17$, at 262.

12. See e.g., Brody, Performance of a Pre-existing Contractual Duty as Consideration, 52 DEN. L.J. 433 (1975); Hillman, Contract Modification under the Restatement (Second) of Contracts, 67 Cornell L. Rev. 680 (1982); Hillman, A Study of Uniform Commercial Code Methodology: Contract Modification under Article Two, 59 N.C.L. Rev. 335 (1981); Hillman, supra note 5, at 849; Mather, Contract Modification under Duress, 33 S.C.L. Rev. 615 (1982). See also Roth Steel Products v. Sharon Steel Corp., 705 F.2d 134 (6th Cir. 1983). As one commentator has noted, the Code approach to policing contract modifications does not generally take into consideration the issue of whether the promisor was influenced by the conduct of the promisee but rather whether the conduct of the promisor was in good or bad faith. In contrast, the common law takes into consideration both the conduct of the promisee and the position of the promisor. Hillman, supra note 5 , at 849,860 .

13. Dawson, Economic Duress-An Essay in Perspective, 45 Mich. L. Rev. 253, 289 (1947). 
It is difficult or impossible for parties to a contract to place terms within the initial contract limiting their subsequent ability to modify the contract. Partly as a result, it is not uncommon for a party to a contract to allege that an unanticipated change in circumstances has occurred which makes it advantageous to breach and pay damages rather than to perform as promised;

It is not uncommon for such statements to induce the other party to agree to a modification of the original contract. When such a statement is not factually accurate-it would not actually be more advantageous for the party to breach and pay damages than to perform-an "empty threat" has been made. The law is understandably disinclined to enforce a modification obtained by such means. By hypothesis, such a modification has no effect on the action that the party making the empty threat would have actually taken-the result is merely a transfer payment from one party to the other not unlike robbery;

The absence of an empty threat is a necessary, but not sufficient, condition for upholding a contract modification. ${ }^{14}$ Even if both parties voluntarily assent to a modification, with no apparent hint of threat or coercion by the proposing party, the modification still must be "fair" and "equitable" to be upheld. ${ }^{15}$ Thus, fairness considerations are more complex in a legal setting than in an economic setting: In the former, it is possible for the proposing party to ask for too much, despite the other party's willingness to pay, whereas in the latter, a modification is fair when it is mutually beneficial, regardless of the degree of benefit received by each party.

The major questions that these facts pose for the economic analysis are the following:

(1) Are available remedies inadequate to deter the hold-up game and, if so, why?

(2) Is there an economic justification for a legal test based upon the fairness of the modification? In particular, is it possible to view such a test as setting a limit upon modifications that the parties would, at the time of making the original contract, have found to be mutually advantageous?

Our analysis concludes that the law correctly distinguishes between those modifications that should be enforced and those that are subject to the holdup game and therefore unenforceable. The findings also confirm that the scope of the term "economic duress" should properly be limited to empty threats. ${ }^{16}$ Specifically, the analysis shows that a policy of refusing to enforce

14. See, e.g., Goebel v. Linn, 47 Mich. 489, 11 N.W. 284 (1882); Watkins \& Son v. Carrig, 91 N.H. 459, 21 A.2d 591 (1941).

15. See, e.g., U.C.C. $§ 1-203$ (1977).

16. See E. FARNSworth, supra note $1, \S 4.17$, at 259-64 for a discussion of the extent to which the term duress has been expanded by courts far beyond its origins. 
modifications based upon empty threats is consistent with the attainment of economic efficiency and is not, therefore, an impediment to the bargaining process. Drawing the line between hard bargaining and duress on an economic basis has the additional advantage of being a clear one for the courts as well as for the parties involved in contract modifications.

Remedies will be shown to provide inadequate protection from the holdup game. This inadequacy does not result from the inability of courts to determine the correct damages or from any unwillingness of the courts to enforce liquidated damage agreements; rather, it derives from the fact that damages large enough to prevent the hold-up game may simply be too expensive in terms of the incentives they provide for inefficient performance. Lastly, it will be shown that the fairness test can be given an objective economic justification as a limitation upon subsequent modifications that would be regarded as mutually advantageous by the parties themselves at the time of initial contracting. Viewed in this light, the fairness test provides parameters for the original contract that are advantageous to both parties at the time of initial contracting that they cannot specify themselves.

The next three sections review the numerous legal rules treating the enforceability of contract modifications. The first examines the use of the common law pre-existing duty rule, which nullifies all contract modifications not supported by additional consideration, whether coerced or not. The next sections examine the modification of the pre-existing duty rule under the Uniform Commercial Code ("the Code") and under the Restatement (Second) of Contracts ("the Restatement"). These sections are followed by a discussion of the hold-up game. The article concludes with our economic analysis of the hold-up game and a brief discussion of the results.

II

\section{The Pre-Existing Duty Rule}

Historically, courts dealt with coercive contract modification by applying the pre-existing duty rule. ${ }^{17}$ According to this rule, doing or promising what a party is already legally bound to do is insufficient consideration for a new promise. ${ }^{18}$ The rule has been applied to a variety of factual contexts, including the promise of a debtor to pay less than the full amount due, ${ }^{19}$ the promise of an owner to pay a contractor more for completion of

17. See, e.g., Rose v. Daniels, 8 R.I. 381 (1866) (agreement by a debtor with a creditor to discharge the debt for a sum less than the amount due is unenforceable because it is not supported by consideration); Lingenfelder v. Wainwright Brewing Co., 103 Mo. 578, 15 S.W. 844 (1891) (modification extorted by an architect from a brewery held to be unenforceable for failure of additional consideration).

18. As Corbin states the rule: "[N]either the performance of duty nor the promise to render a performance already required by duty is sufficient consideration for a return promise." 1A A. Corbin, supra note $8, \S 171$, at 105 . See also 2 A. Squillante \& J. Fonseca, Williston on Sales $\S 12$ 2, at 3 (4th ed. 1974); J. Calamari \& J. Perillo, Contracts § 4-9, at 204 (3d ed. 1987).

19. Rose v. Daniels, 8 R.I. 381 (1866). 
construction, ${ }^{20}$ a promise of an employer to pay more to an employee for his work, ${ }^{21}$ and a promise of a buyer to pay more to a seller for goods. ${ }^{22}$

A classic example of the application of the rule is found in Alaska Packers' Association $v$. Domenico. ${ }^{23}$ There, a number of seamen contracted with Domenico to sail to Alaska to fish for salmon during the annual salmon run. Subsequent to their arrival at the fishing grounds, the men refused to work unless they were paid more for their labor than the parties had originally agreed. Because it was impossible for Domenico to find other men, he agreed to pay the additional rate demanded. Once the men returned to their home port, Domenico refused to pay them the additional money. The court found that the subsequent agreement to pay the men the additional monies was not supported by consideration because the men had a pre-existing duty to harvest the fish under the original contract. Thus, the subsequent agreement was unenforceable.

This rule was originally widely accepted in the common law of the United States. ${ }^{24}$ As suggested by Judge Posner, "[a]llowing contract modifications to be voided in circumstances such as those in Alaska Packers' Association assures prospective contract parties that signing a contract is not stepping into a trap, and by thus encouraging people to make contracts promotes the efficient allocation of resources." 25

While the rationale behind such an absolute rule is technically expressed in terms of absence of consideration, some authorities suggest that the justification for the rule really rests on the concern that the new promise by the responding party may have been made under economic duress and therefore should not be upheld. ${ }^{26}$ As previously noted, such situations are characterized by Corbin as the hold-up game ${ }^{27}$ and involve empty threats, that

20. Lingenfelder v. Wainwright Brewing Co., 103 Mo. 578, 15 S.W. 844 (1891).

21. Alaska Packers' Ass'n v. Domenico, 117 F. 99 (9th Cir. 1902).

22. Rexite Casting Co. v. Midwest Mower Corp., 267 S.W.2d 327 (Mo. C. App. 1954).

23. 117 F. 99 (9th Cir. 1902).

24. Ruffin v. Mercury Record Prods., Inc., 513 F.2d 222 (6th Cir. 1975), cert. denied, 423 U.S. 914 (1975); Mobile Turnkey Housing, Inc. v. Ceafco, Inc., 294 Ala. 707, 321 So. 2d 186 (1975); Healy v. Brewster, 59 Cal. 2d 455, 380 P.2d 817, 30 Cal. Rptr. 129 (1963); Dunn v. Utica Ins. Co., 108 Ga. 368, 133 S.E.2d 60 (1963); Insurance Agents, Inc. v. Abel, 338 N.W.2d 531 (Iowa App. 1983); Rudio v. Yellowstone Merchandising Corp., 200 Mont. 537, 652 P.2d 1163 (1982); Schwartzreich v. Bauman-Basch, Inc., 231 N.Y. 196, 131 N.E. 887 (1921). See also Patterson, An Apology for Consideration, 58 Colum. L. Rev. 929, 936 (1958).

25. Selmer Co. v. Blakeslee-Midwest Co., 704 F.2d 924, 927 (7th Cir. 1983).

26. 1A A. Corbin, supra note $8, \S 184$, at $148-49$. The thesis that the pre-existing duty rule is concerned with the issue of duress is also suggested by Judge Posner in Selmer v. Blakeslee-Midwest Co., 704 F.2d 924 (1983). See also Brody, supra note 12, at 435.

27. In explaining the rule, Corbin states:

Doubtless, also, there have been tough cases in which the promisor has been subjected to a hold up game, so that he made his new promise under some degree of economic duress. It is certainly possible that a contractor may bid low in order to get the contract, and then refuse to perform, after it is too late to obtain another contractor without loss and inconvenience, in order to induce a promise of more pay. The strict enforcement of the supposed general rule would tend to remove this temptation from bidders, since they would know that a promise so induced would not be legally enforceable.

1A A. Corbin, supra note 8, at 105. 
is, attempts to exploit the contract responding party's lack of an adequate legal remedy when no genuine dispute exists between the parties. Such empty threats involve a promise to refrain from an action that would not have been taken anyway. Since there is no detriment involved in promising not to do what one would not have done anyway, and since there is no benefit to the other party in obtaining what he would have obtained anyway, it is our opinion that duress, when so viewed, is equivalent to a lack of consideration.

Although the pre-existing duty rule possesses the virtue of certainty (no modifications will be allowed absent additional consideration), ${ }^{28}$ the doctrine has been criticized ${ }^{29}$ as being both overinclusive and underinclusive. ${ }^{30}$ It is overinclusive to the extent that it represents a serious impediment to good faith contract modifications. Because of its absoluteness, it fails to distinguish between situations in which the party desiring modification is in fact playing a hold-up game and one in which such party is motivated by the discovery of circumstances or the occurrence of unexpected events that makes his performance far more burdensome than originally expected. ${ }^{31}$ It is underinclusive to the extent that even if bad faith or overreaching underlies the party's desire to modify, if it is coupled with even the most modest form of consideration, then the modification will be upheld. ${ }^{32}$

The pre-existing duty rule gradually lost favor with the courts as they began to realize that it often produced an unfavorable result. Thus, courts began to formulate a number of legal fictions to circumvent the rule. Using one such fiction, a number of courts found that the rule was inapplicable to situations in which the parties mutually rescinded the agreement prior to execution of the new agreement. ${ }^{33}$ Under this rationale, the new promise to accept less or to pay more consideration would be supported by the other

28. See, e.g., 1A A. Corbin, supra note $8, \S 184$, at 265 , § 171, at 246; E. FARNSworTH, supra note $1, \S 4.21$, at 274; Hillman, supra note 5 , at 64 .

29. As Corbin stated:

There has been a growing doubt as to the soundness of this doctrine as a matter of social policy. In certain classes of cases, this doubt has influenced courts to refuse to apply the rule, or to ignore it, in their actual decisions. Like other legal rules, the rule is in the process of growth and change, the process being more active here than in most instances. The result of this is that a court should no longer accept this rule as fully established.

1A A. Corbin, supra note $8, \S 171$, at 105 .

30. E. FaRNSWORTH, supra note $1, \S 4.21$, at 274.

31. Compare, for example, the facts of Alaska Packers Ass'n v. Domenico, 117 F. 99 (9th Cir. 1902), with Davis \& Co. v. Morgan, 117 Ga. 504, 43 S.E. 732 (1903). In the former case, workers refused, without justification, to perform services under a contract with Alaska Packers' unless they received additional compensation. In the latter case, Morgan, an employee of Davis \& Co., received a better job offer from another company. The employer offered to increase Morgan's compensation in order to induce Morgan to remain at Davis \& Co. This promise was later held to be unenforceable for failure of consideration. These cases are also cited in E. FARNSWORTH, supra note 1, § 4.21, at 274 n. 19 .

32. Since courts generally do not inquire into the fairness of the consideration exchanged, even a "horse, hawk or a robe" is sufficient consideration. E. Farnsworth, supra note $1, \S 4.21$, at 274 (referencing language used by Lord Coke in Pinnel's Case, 5 Coke's Rep. at 117a-117b, 77 Eng. Rep. at 237 (C.P. 1602)).

33. See, e.g., Martiniello v. Bamel, 255 Mass. 25, 150 N.E. 838 (1926); Schwartzreich v. BaumanBasch, Inc., 231 N.Y. 196, 131 N.E. 887 (1921). 
party's renewed promise to perform the work originally agreed upon. These courts were not generally concerned with the fairness of either the rescission or the new contract. ${ }^{34}$

Other courts circumvented the rule by finding that the responding party had, through gift, waiver, or release, relieved the other party of his obligations under the earlier contract. ${ }^{35}$ As one commentator has noted, ${ }^{36}$ these efforts to circumvent the pre-existing duty rule had a common inherent flaw: They were based on the premise that one party wanted to release the other party from any obligations before the parties entered into the second contract. In point of fact, however, neither party intended that the other would have an absolute right to avoid the contract. ${ }^{37}$

Still other courts attempted to avoid the unfairness of the pre-existing duty rule by finding additional consideration to support the new promise. ${ }^{38}$ The new consideration (or legal detriment) existed in the party desiring modification's promise not to breach. Under this rationale, however, the new consideration could always be found, thereby supporting enforcement of the new promise in every case in which the rationale was applied. Even unfair or coercive modifications would be upheld. In effect, this rationale conferred upon the party desiring modification a right to breach, a notion that some authorities have challenged. ${ }^{39}$

Finally, some courts simply ignored the pre-existing duty rule and its attendant requirement for new consideration in contract modifications by creating an exception. These courts concluded that if the responding party promised to pay an additional sum for the work, and if the demand by the party seeking modification was based on unforeseen difficulties, then such a modification without consideration would be enforceable. ${ }^{40}$ As stated by one court, this exception to the pre-existing duty rule should be limited to instances "where the refusal to perform was equitable and fair, and the difficulties were substantial, unforeseen and not within the contemplation of the parties when the original contract was made."41 The unforeseen difficulties envisioned here presumably create circumstances in which it would be better for the party desiring modification actually to breach than to

34. E. FARNSWORTH, supra note $1, \S 4.21$, at 274 .

35. See Watkins \& Son v. Carrig, 91 N.H. 459, 21 A.2d 591 (1941); Meech v. City of Buffalo, 29 N.Y. 198 (1864).

36. See Hillman, Contract Modification in Iowa-Recker v. Gustafson and the Resurrection of the Preexisting Duty Doctrine, 65 Iowa L. REv. 343, 346-47 (1980).

37. Id.

38. See E. Farnsworth, supra note 1, § 4.21, at 275; Hillman, supra note 36, at 343, 347.

39. See J. Calamari \& J. Perillo, supra note 18, § 4-9, at 207; J. Murray, Contracts 179 (1974); but see O.W. Holmes, The Common Law 298-302 (1923).

40. See, e.g., United States v. Cook, 257 U.S. 523 (1922); Merrill-Stevens Dry Dock \& Repair Co. v. United States, 96 F. Supp. 464 (Ct. Cl. 1951); Mobile Turnkey Housing, Inc. v. Ceafco, Inc., 294 Ala. 707, 321 So. 2d 186 (1975); Angel v. Murray, 113 R.I. 482, 322 A.2d 630 (1974).

41. Linz v. Schuck, 106 Md. 220, 233, 67 A. 286, 289 (1907); accord Watkins \& Son v. Carrig, 91 N.H. 459, 21 A.2d 591 (1941). See also Goebel v. Linn, 47 Mich. 489, 11 N.W. 284 (1882). This view has been adopted by the Restatement (Second) of Contracts $\$ 89$ (1981): "A promise modifying a duty under a contract not fully performed on either side is binding . . . if the modification is fair and equitable in view of circumstances not anticipated by the parties when the contract was made ...." 
perform as originally promised. To give up the legal right to breach in such circumstances is clearly a detriment to the party desiring modification since it involves forsaking the preferred course of action and should, in our view, be regarded as additional consideration supporting the modification. The refusal to perform is not an empty threat in such circumstances. Conversely, if the unforeseen difficulties do not create circumstances in which the requesting party would actually find it advantageous to breach rather than to perform as originally promised, then giving up the right to breach is neither a detriment to the party desiring modification nor a benefit to the responding party and should not be regarded as additional consideration. Here the refusal to perform is an empty threat. In this view, the unforeseen circumstances exception to the pre-existing duty rule would not have been necessary had courts adopted the proper empty threat test of consideration: Would it have been in the party's best economic interest actually to make good on the threat if concessions had not been obtained?

\section{III}

\section{Statutory Modification of the Pre-Existing Duty Rule}

The Code does not require consideration as a predicate for the enforceability of modifications of contracts involving goods. ${ }^{42}$ Under section 2-209 of the Code, "an agreement modifying a contract within this Article needs no consideration to be binding." 43 In so providing, the creators of the Code were acknowledging one of the fallacies of the pre-existing duty rule: That without consideration, no contract modifications would be recognized, whether coerced or made voluntarily by the parties.

Although the creators of the Code recognized the weaknesses inherent in the pre-existing duty rule, they also recognized the legitimate concern raised

42. Obviating the requirement of consideration in contract modifications does not suggest that such a requirement may also be dispensed with in the original agreement. The consideration necessary to an original agreement serves to enforce the notion that the parties seriously and voluntarily entered into the transaction and provides each with something in return for his promise. See Fuller, Consideration and Form, 41 Colum. L. Rev. 799 (1941); Hillman, supra note 36, at 344 n.6. As explained in the case of Watkins $\mathcal{E}$ Son, Inc., $91 \mathrm{~N} . \mathrm{H}$. at $462,21 \mathrm{~A} .2 \mathrm{~d}$ at 593 , the issue of consideration in the contract modification context is entirely separate from that in the underlying contract:

In common understanding there is, importantly, a wide divergence between a bare promise and a promise in adjustment of a contractual promise already outstanding. A promise with no supporting consideration would upset well and long-established human interrelations if the law did not treat it as a vain thing. But parties to a valid contract generally understand that it is subject to any mutual action they may take in its performance. Changes to meet changes in circumstances and conditions should be valid if the law is to carry out its function and service by rules conformable with reasonable practices and understandings in matters of business and commerce.

But see G. Gilmore, The Death of Contract 18-34 (1974).

43. U.C.C. $\S 2-209(1)$ comment 1 (1977) identifies the reason for this rule: "This section seeks to protect and make effective all necessary and desirable modifications of sales contracts without regard to the technicalities which presently hamper such adjustments." 
by the hold-up game which the rule tried to prevent. ${ }^{44}$ The Code addresses this issue in rather oblique fashion. There is no policing mechanism set forth in section 2-209, but the comments to this section attempt to deal with the problem of coercive modifications. Comment 2 to section 2-209 states that " modifications made [under this section] must meet the test of good faith . . . The effective use of bad faith to escape performance on the original contract terms is barred, and the extortion of a 'modification' without legitimate commercial reason is ineffective as a violation of the duty of good faith. Nor can a mere technical consideration support a modification made in bad faith." 45

Although it is commendable to require that contract modifications be made in good faith, the drafters of the Code left us with no clear interpretation of the applicability of such a requirement to contract modifications. There are two different Code definitions of good faith found in other sections, and a Code definition of unconscionability, ${ }^{46}$ all of which seem to bear on the issue of good faith. Section 1-201(19) defines the term "good faith" in relation to all transactions to which the Code applies: "Good faith means honesty in fact in the conduct or transaction concerned." 47 The test under this section has been interpreted as a subjective one, known as "the rule of the pure heart and the empty head." 48 However, a stricter, enhanced definition is applied in the case of a merchant: Section 2-103(b) combines the subjective test of honesty in fact with an objective test of "the observance of reasonable commercial standards of fair dealing in the trade." 49 The objective part of the test is, as one court noted, 50 fairly straightforward. The party seeking enforcement of the modification must show that his decision to

44. U.C.C. $§ 2-209$ comment 2 (1977). The last sentence of this comment obviates one of the problems raised by the pre-existing duty rule but which remains unsolved: If consideration exists, but the modification was made in bad faith, then the bald presence of the consideration will not support the modification. See generally Hillman, supra note 5 , at 849 .

45. U.C.C. $\$ 2-302$ (1977). Although this section will not be discussed, the text is set forth below: "If the court as a matter of law finds the contract or any clause of the contract to have been unconscionable at the time it was made the court may refuse to enforce the contract, or it may enforce the remainder of the contract without the unconscionable clause, or it may so limit the application of any unconscionable clause as to avoid any unconscionable result."

46. The Uniform Commercial Code has a specific section which requires good faith in all Code transactions. Section 1-203 states: "Every contract or duty within this Act imposes an obligation of good faith in its performance or enforcement." Although this section does not apply to contract formation, it does apply to contract modification which deals with "performance" under the contract. J. Calamari \& J. Perillo, supra note 18, § 11-38, at 509. Further, the official comment to this section points out that under the sales definition of good faith ( $\$ 2-103)$, merchants not only have the obligation of honesty in fact, but are also required to observe reasonable commercial standards of fair dealing in the trade.

47. U.C.C. § 1-201(19) (1977).

48. Braucher, The Legislative History of the Uniform Commercial Code, 58 Colum. L. REv. 798, 812 (1958). A number of commentators have criticized the lack of an objective standard in this section. See, e.g., Farnsworth, Good Faith Performance and Commercial Reasonableness under the Uniform Commercial Code, 30 U. Chi. L. Rev. 666 (1963); Summers, "Good Faith" in General Contract Law and the Sales Provisions of the Uniform Commercial Code, 54 VA. L. Rev. 195, 208-16 (1968).

49. For a comprehensive examination of good faith under the Uniform Commercial Code, see Hillman, supra note 5 , at 849 .

50. Roth Steel Products v. Sharno Steel Corp., 705 F.2d 134, 146 (6th Cir. 1983). 
seek a modification was based on factors, such as increased costs, that would cause an ordinary merchant to seek modification of the contract. The second inquiry, regarding the subjective honesty of the party seeking modification, is far more problematic, however. The burden is on the party asserting the modification to show that he was, in fact, motivated by a legitimate commercial reason and that such a reason is not offered as a mere pretext. ${ }^{51}$ The court must determine whether the means used to obtain the modification are an impermissible attempt to obtain a modification by extortion or overreaching. ${ }^{52}$

While White and Summers may be right that judges can use sections 1-203 and 2-302 on bad faith and unconscionability to police against the extortionist, the profiteer, the chiseler, and the dishonest compromiser, guidelines are far from clear..$^{53}$ The difficulty of interpreting and applying the Code's definition of good faith is illustrated by the following hypothetical situation: Suppose a merchant has a legitimate commercial reason for demanding a price increase, but the amount he demands is excessive under market conditions. Does comment 2 to section 2-209 require that his reason for the modification be legitimate, or that the amount be legitimate, or both? ${ }^{54}$ As one commentator has noted:

While the repudiation of the pre-existing duty doctrine in section 2-209(1) was a major step, the issues and problems in determining the enforceability of modifications are largely the same under the Code as at common law. At common law, fictions such as waiver and mutual rescission used to avoid the pre-existing duty rule were employed only when the courts were convinced that the modification was not a product of overreaching. The Code approach to overreaching-the obligation of good faith performance-cuts through the thicket of pre-existing duty and consideration questions, but substitutes for that thicket one of its own: the meaning and proper application of good faith. ${ }^{55}$

Thus, section 2-209(1) provides for contract modification without the requirement of additional consideration but only if two conditions are met. First, the party desiring modification must demonstrate that he was acting in good faith-that his request for a modification was based on a legitimate commercial reason-and that such reason is not offered as a mere pretext to extort a higher sum from the other party. This rule, as noted, does do away with a number of problems presented by the restrictive pre-existing duty rule but is not easy to apply because of the difficulty of interpreting the term "good faith."

51. Ralston Purina Co. v. McNabb, 381 F. Supp. 181, 183 (W.D. Tenn. 1974).

52. See Erie County Water Auth. v. Hen-Gar Constr., 473 F. Supp. 1310, 1313 (W.D.N.Y. 1979); J. White \& R. Summers, supra note 3, § 1-6, at 59-61.

53. See Hillman, supra note 5 , at 849,862 .

54. For a discussion of the difficulty that courts have experienced in interpreting the "good faith" standard under section 2-209, see generally Hillman, supra note 5 , at 849 .

55. Hillman, supra note 5, at 875-76. 


\section{IV}

\section{Further Erosion of the Pre-Existing Duty Rule}

Section 89 of the Restatement ${ }^{56}$ has further eroded the common law doctrine of the pre-existing duty rule. This section has been strongly influenced by section 2-209 of the Code ${ }^{57}$ and, like the Code, permits modification of contractual duties without consideration in the context of modifications to an ongoing business transaction. Under the topic, "Contracts Without Consideration," the Restatement provides: "A promise modifying a duty under a contract not fully performed on either side is binding (a) if the modification is fair and equitable in view of circumstances not anticipated by the parties when the contract was made . . ."58

The rationale for the Restatement approach appears to derive from the common law "unanticipated circumstances" exception to the pre-existing duty rule. ${ }^{59}$ Comment b to section 89 of the Restatement elaborates on the meaning of "circumstances not anticipated" by stating that an event, even if foreseen as a remote possibility, may be unanticipated if it was not adequately covered in the agreement. ${ }^{60}$ This is not a satisfactory explanation of the term; it is unclear how the section will be applied. The often cited case Angel $v$. Murray ${ }^{61}$ relies on this very language in the Restatement to uphold a modification without consideration. In that decision, Mr. Maher had entered into a series of five-year contracts with the City of Newport to collect refuse. Subsequent to entering into the final five-year contract for a stated sum, the cost of refuse collection substantially increased owing to an unexpected and unanticipated increase of the dwellings in the area by 400 . Mr. Maher thereafter requested a modification to the original contract whereby he would receive an additional $\$ 10,000$ for each of the remaining three years of the contract. The city council agreed to this modification. Mr. Maher received the additional monies for two of the remaining three years; after the second

56. This section first appeared as $\S 89 \mathrm{D}$ in the 1965 tentative draft of the Restatement (Second) and was intended as an exception to the rule that "moral obligations" are not consideration for a binding promise. See lA A. Corbin, supra note $8, \S 239$, at $384 \mathrm{n} .28$ (criticizing overgenerality of presection 89 rule). For the theoretical underpinnings of section 89 , see Fuller, supra note 42 , at 799 , 806-10.

57. See J. Calamari \& J. Perillo, supra note 18, § 4-9, at 206.

58. Restatement (Second) of Contracts $\$ 89$ (1981).

59. The following cases have adopted or recognized explicitly or implicitly the unanticipated circumstances exception to the pre-existing duty rule. See, e.g., Wright \& Pierce v. Wilmington, 290 F.2d 30 (1st Cir. 1961); Frommeyer v. L. \& R. Constr. Co., 261 F.2d 879 (3d Cir. 1958); Fran Realty, Inc. v. Thomas, 30 Md. App. 362, 354 A.2d 196 (1976); Mobile Turnkey Housing, Inc. v. Ceafco, Inc., 294 Ala. 707, 321 So. 2d 186 (1975); Evergreen Amusement Corp. v. Milstead, 206 Md. 610 , 112 A.2d 901 (1955); Blakeslee v. Board of Water Comm'rs, 106 Conn. 642, 139 A.106 (1927); Linz v. Schuck, 106 Md. 220, 67 A. 286 (1907); King v. Duluth, M. \& N.R. Co., 61 Minn. 482,63 N.W. 1105 (1895); Goebel v. Linn, 47 Mich. 489, 11 N.W. 284 (1882).

60. Restatement (Second) of Contracts $\$ 89$ comment b (1981). One commentator has suggested that the Restatement approach is more liberal in enforcing amendments than the similar exception to the pre-existing duty rule in that it does not require that circumstances be unforeseen, but only that they be unanticipated even if remotely foreseeable by the parties. See Mather, supra note 12 , at 615,619 n. 16 .

61. 113 R.I. 482, 322 A.2d 630 (1974). 
year, the citizens of Newport brought an action to compel him to return the additional $\$ 20,000$ which he had received. The Supreme Court of Rhode Island expressly relied on section 89 of the Restatement ${ }^{62}$ in finding that the contract modification between Mr. Maher and the City of Newport should be upheld. The court noted that the modern trend of the law is to enforce agreements modifying contracts when "unexpected or unanticipated difficulties arise during the course of the performance of a contract, even though there is no consideration for the modification, as long as the parties agree voluntarily."'63

It can be argued that the "unanticipated circumstances" of section 89 of the Restatement can be equated with the "legitimate commercial reasons" of Code section 2-209, discussed previously.64 Similarly, the "fair and equitable" requirement under section 89 has its parallel in Code section 2209 under the "good faith" standard.65 The meaning of "fair and equitable" in Restatement section 89 is elaborated upon in comment b, which states that " $[\mathrm{t}]$ he limitation to a modification which is 'fair and equitable' goes beyond absence of coercion and requires an objectively demonstrable reason for seeking a modification." 66 Several courts have interpreted the language "fair and equitable" to require an absence of coercion, duress, or extortion. ${ }^{67}$

Similar to its statutory counterpart under the Code, section 2-209(1), the Restatement alleviates a number of the problems found in the pre-existing duty rule. In order for a contract modification to be enforceable if no additional consideration has changed hands, several conditions must be met. The request for the modification must be based on circumstances that were unanticipated by the parties at the time of entering into the contract. Further, the request for the modification must appear to the courts fair and equitable in light of the circumstances.

\section{V \\ The Hold-Up Game}

In examining the enforceability of contractual modifications without consideration, the doctrine of economic duress ${ }^{68}$ must be considered in order to analyze the enforceability of contracts subject to a hold-up game. ${ }^{69}$ With the demise of the pre-existing duty rule and the increased acceptance of

62. Id. at $493-94,322 \mathrm{~A} .2 \mathrm{~d}$ at 636 . At the time of the decision, the Restatement (Second) $\S 89$ had not yet been adopted. The decision was therefore based on the draft section $89 \mathrm{D}$.

63. Id.

64. See U.C.C. § 2-209 comment 2 (1977).

65. Id.

66. Restatement (Second) of Contracts $\$ 89$ comment b (1981).

67. See, e.g., Lowey v. Watt, 684 F.2d 957, 968-69 (D.C. Cir. 1982); Angel v. Murray, 113 R.I. 482, 489-94, 322 A.2d 630, 630-37 (1974).

68. Duress may be defined as a threat or wrongful act which overcomes the free will of a party. J. Calamari \& J. Perillo, supra note 18, § 9-2, at 337. For a general discussion of economic duress and its application to contract modifications, see Dalzell, Duress by Economic Pressure, 20 N.C.L. REv. 254 (1942); Dawson, supra note 13; Hillman, supra note 5, at 849, 880-99.

69. See supra notes 13-14 and accompanying text. 
contract modifications not supported by additional consideration, the use of the defense of duress to thwart a contract modification has gained increasing judicial attention and interpretation. ${ }^{70}$ Consider the following illustration. A subcontractor has contracted with $X$ to supply him with certain pipe. The subcontractor, finding that the price of the pipe has risen to the extent that he can no longer make a profit at the contract price, tells the contractor that he refuses to perform unless he is paid the higher sum, $Y$. The contractor, knowing that he cannot find the same pipe from another supplier in time to meet his deadline with the owner, agrees to the subcontractor's terms. As Posner notes, "[t]here is a practical argument against treating such a statement as a threat: it will make an inference of duress inescapable in any negotiation where one party makes an offer from which it refuses to budge, for the other party will always be able to argue that he settled only because there was a (figurative) gun at his head." 11 Indeed, older cases have held that a threat not to honor a contract could not be considered duress. ${ }^{72}$ However, recent cases have held that a threat to breach the contract may constitute economic duress if certain conditions prevail. ${ }^{73}$ If the threat is deemed wrongful and the responding party has no reasonable alternative or no adequate legal or equitable remedy, then the threat may constitute duress. ${ }^{74}$ Both the Restatement and the Code address the issue of wrongful threat of breach. Section $176(1)(d)$ of the Restatement states that a threat is improper if "the threat is a breach of the duty of good faith and fair dealing under a contract with a recipient." 75 Under the Code, as mentioned above, a modification is judged in terms of "reasonable commercial standards of fair

70. See, e.g., First Data Resources, Inc. v. Omaha Steaks Int'l, Inc., 209 Neb. 327, 307 N.W.2d 790 (1981); Wurtz v. Fleischman, 97 Wis. 2d 100, 293 N.W.2d 155 (1980); Ross Systems v. Linden Dari-Delite, Inc., 35 N.J. 329, 173 A.2d 258 (1961); Thompson Crane \& Trucking Co. v. Eyman, 123 Cal. App. 2d 904, 267 P.2d 1043 (1954).

71. Selmer Co. v. Blakeslee-Midwest Co., 704 F.2d 924, 927 (7th Cir. 1983).

72. See, e.g., Hartsville Oil Mill v. United States, 271 U.S. 43 (1926); Steinberg Press, Inc. v. Charles Henry Publications, Inc., 68 N.Y.S.2d 793 (N.Y. Sup. Ct. 1947); Sistrom v. Anderson, 51 Cal. App. 2d 213, 124 P.2d 372 (1942). But see Alaska Packers' Ass'n v. Domenico, 117 F. 99 (9th Cir. 1902).

73. See, e.g., Lowey v. Watt, 684 F.2d 957, 968-69 (D.C. Cir. 1982); Angel v. Murray, 113 R.I. 482, 489-94, 322 A.2d 630, 630-37 (1974).

74. See, e.g., Austin Instrument, Inc. v. Loral Corp., 29 N.Y.2d 124, 272 N.E.2d 533, 324 N.Y.S.2d 22 (1971), wherein the court held a contract voidable on the basis of duress:

A contract is voidable on the ground of duress when it is established that the party making the claim was forced to agree to it by means of a wrongful threat . . . However, a mere threat by one party to breach the contract by not delivering the required items, though wrongful, does not in itself constitute economic duress. It must also appear that the threatened party could not obtain the goods from another source of supply and that the ordinary remedy of an action for breach of contract would not be adequate.

Id. at 131-32, 272 N.E.2d at 535, 324 N.Y.S.2d at 25-26. See also J. Calamari \& J. Perillo, supra note 18 , $\$ 9-6$, at 345-48; Dalzell, supra note 68 , at 237,341 . The Code itself does not stipulate that a threat to breach a contract leave the promisor with no reasonable alternative, but, as one commentator has noted, it would make sense to infer such a requirement. E. FarNsworTH, supra note $1, \S 4.22$, at 278 n.9.

75. Restatement (Second) of Contract $\S 176(1)(d)$ (1981). Comment e to the Restatement notes that "the extortion of a 'modification' without legitimate commercial reason is ineffective as a violation of the duty of good faith . . . . The test of 'good faith' between merchants or as against merchants includes observance of reasonable commercial standards of fair dealing in the trade 
dealing in the trade" and in terms of the legitimate commercial rationale for the modification. ${ }^{76}$

On the other hand, "hard bargaining between experienced adversaries ought not to be discouraged." 77 Courts have held that a responding party may be held to his bargain even if agreed to under adverse circumstances so long as the contract is in fact shaped by prevailing market forces. ${ }^{78}$ The key, as suggested by the Restatement, is whether "what is threatened is ... a use of power for illegitimate ends." 79 Thus, at issue is the fairness of the terms of the modification.

The law will accommodate the parties to a contract who seek a modification. However, a court will enforce the modification only if the court is satisfied that the party seeking modification is not engaging in a hold-up game; the modification will be enforced only if the refusal to perform is not an empty threat, and the modification is fair and equitable in light of the circumstances surrounding the transaction. It is the duty of the court to determine which contract modifications were freely entered into and which were a product of the hold-up game.

\section{VI}

\section{Economic Analysis}

We now turn to an economic analysis of the hold-up game. As noted in the Introduction, the major questions to be answered are the following:

(1) Are available remedies inadequate to deter the hold-up game and, if so, why?

(2) Is there an economic justification for a legal test based upon the fairness of the modification? In particular, is it possible to view such a test as setting a limit upon modifications that the parties would, at the time of making the original contract, have found to be mutually advantageous?

Answers to these questions would ideally be consistent with several other facts:

- The legal importance of unanticipated events suggests, at a minimum, that some uncertainty exists at the time of contracting which is resolved prior to the time at which performance is supposed to be completed.

\footnotetext{
(section 2-103), and may in some situations require an objectively demonstrable reason for seeking a modification." Id. comment e (quoting U.C.C. § 2-209).

76. U.C.C. \& 2-209 comment 2 (1977).

77. E. Farnsworth, supra note $1, \S 4.17$, at 263.

78. Id.; see, e.g., Carpenter Paper Co. v. Kearney Hub Publishing Co., 163 Neb. 145, 78 N.W.2d 80 (1956). The court found that the promise was not unenforceable based on the theory of economic duress because the promisee merely sought to handle the contract on a more profitable basis and had a perfect right to do so "if, in doing so, it did not make unjust demands upon [promisor] in view of all the circumstances then existing." Id. at 152, 78 N.W.2d at 84 . See also United States v. Bethlehem Steel Corp., 315 U.S. 289 (1942); Standard Box Co. v. Mutual Biscuit Co., 10 Cal. App. 746, 103 P. 938 (1909).

79. Restatement (Second) of Contracts $§ 176(2)$ (c) (1981).
} 
- Behavior of the parties in the modification-performance and litigation stages is apparently characterized by mixed strategies. Parties who have agreed to modifications do not uniformly sue to have them set aside. And parties who request modifications are only sometimes justified by changes in their circumstances.

- For an empty threat to be effective (that is, believable), the fact that it would not be advantageous to the party making the threat must not be known to the other partythere must be an information asymmetry for such behavior to be a (sub-game perfect) equilibrium.

We now turn to an examination of a simple game whose equilibrium is consistent with the stylized facts and which provides some interesting answers to the above questions. Imagine for concreteness a service contract between a risk-neutral buyer and a risk-neutral seller. At the time of contracting it is common knowledge that the value of the service to the buyer is a random variable that will, for simplicity, either be high, $v_{h}$, or low, $v_{l}$, where $v_{h}>v_{l}>$ 0 . It is also common knowledge that the "reliance loss" that the buyer will suffer should the seller not perform is another random variable that will either be high, $r_{h}$, or low, $r_{l}$, where $r_{h}<r_{l}<0$. The probability that the buyer will experience the state $\left(v_{l}, r_{j}\right)$ will be denoted $p_{\imath}>0$ for $i, j=l, h$. Finally, it is common knowledge that the cost to the seller of performing is an independent random variable that will either be high, $c_{h}$, or low, $c_{l}$, with probabilities $q_{k}>0 k=l, h$, respectively, where $c_{h}<c_{l}<0$.

The timing of the game is as follows:

\section{Contract $\rightarrow$ Information Revealed $\rightarrow$ Modification and/or Performance $\rightarrow$ Litigation}

First, the parties enter into a contract. After contracting but prior to completion of performance, information regarding the actual realizations of the random variables is given to the parties. Next, the parties have an opportunity for modification and completion of performance and finally an opportunity for litigation.

Whether or not it would actually be efficient for the seller to perform in state $\left(v_{l}, r_{j}, \mathrm{c}_{k}\right)$ depends upon whether or not the joint payoff to completion of performance $v_{l}+c_{k}$, exceeds the joint payoff to not completing performance, $r_{j}$. Let $P$ denote the states in which performance is efficient:

$$
P \equiv\left\{(i, j, k) \mid v_{\imath}+c_{k} \geq r_{j}\right\}
$$

Whether the buyer and seller can achieve an efficient outcome depends, of course, on the information that becomes available to each in the course of the game. In the "information revealed" stage, it is assumed, at a minimum, that seller learns the actual value of $c$ and the buyer learns the actual values of $v$ and $r$. In this "minimum information" setting the seller's actual cost is private information to the seller-known only to the seller-and the actual value of the service and reliance loss are private information to the buyer. 
A. When Only One Party Has Private Information

Two more informative cases provide a useful benchmark for subsequent analysis:

(1) Only the buyer's information is private-it is common knowledge that the buyer learns the value of $v, r$, and $c$ and the seller only learns $c$.

(2) Only the seller's information is private-it is common knowledge that the seller learns the value of $v, r$, and $c$ and the buyer only learns $v$ and $r$.

Consider Case 1 and an option contract in which the buyer has an option of offering a bonus to the seller at the time of performance equal to either $0,-c_{l}$ $>0$, or $-c_{h}>0$. The seller is free either to accept the bonus and perform or to reject the bonus and not perform. Note that the buyer must offer the seller a minimum of $b=-c_{k}$ to induce the seller to perform in state $\left(v_{i}, r_{j}, c_{k}\right)$. Given this constraint the buyer can do no better than to adopt the following strategy regarding the bonus, $b_{\imath \jmath k}$, offered in state $\left(v_{\imath}, r_{\jmath}, c_{k}\right)$ :

$$
b_{\imath j k} \equiv \begin{cases}-c_{k} & \text { if }(i, j, k) \in P \\ 0 & \text { otherwise }\end{cases}
$$

The seller can do no better than to respond by accepting (and performing) when $b={ }_{\imath \jmath k}>0$ and not performing when $b={ }_{i j k}=0$. This equilibrium is (full information) Pareto efficient. ${ }^{80}$ The initial price of the option contract can be used to distribute the gains between the parties.

Case 2 is symmetric. Here the option contract offers the seller a chance to demand a bonus for performing equal to either $\infty$ or $v_{i}-r_{j}$, for $i, j=l, h$. The buyer is free either to accept the demand-pay the bonus and receive the value of performance-or to reject the demand and receive the reliance loss associated with no performance. Here the seller must demand a maximum of $v_{\imath}-r_{j}$ to induce the buyer to accept in state $\left(v_{l}, r_{j}, c_{k}\right)$. Given this constraint the seller can do no better that to adopt the strategy:

$$
b_{\imath \jmath k} \equiv \begin{cases}v_{\imath}-r_{j} & \text { if }(i, j, k) \in P \\ \infty & \text { otherwise. }\end{cases}
$$

The buyer can do no better than to accept when $b$ is finite and reject otherwise. This equilibrium is again (full information) Pareto efficient and the initial price of the contract can once again be used to distribute the gains between the parties. Full information Pareto efficient outcomes are possible when only one party is privately informed.

Note that in both cases the game's description contains a provision analogous to the ability of the parties to limit their subsequent ability to modify the original contract. It is assumed, for example, in Case 1 that it is not possible for the seller to wait for the buyer's offer and then ask for more. Were this possible the seller might be inclined to reject the buyer's offer and threaten

80. See supra note 2 and accompanying text. 
not to perform unless paid an amount equal to the expected value of $v-r$ given that $v-r \geq c_{k}$. Such a threat, however, would not be credible to the buyer who knows the seller's actual cost and knows, therefore, that it would not be rational for the seller actually to carry out such a threat. For such a hold-up game to be possible, asymmetric information is not sufficient-both parties must have private information.

\section{B. When Both Parties Have Private Information}

The interesting case and the focal one for our examination of the hold-up game is the one in which both parties have private information-the minimum information setting described above. Suppose initially that the contract specifies a "liquidated damages" payment $d$ to be paid by the seller to the buyer if the contract is not modified and if the seller does not perform. Furthermore, the contract specifies that the seller may, at his option, demand a bonus payment $b$ for performing. The buyer has the right to reject this "modification" and insist upon the terms of the original contract. Should the buyer accept the modification, the buyer retains the right to "litigate" which, for our purposes, means that the buyer can demand an audit, which requires an expenditure of $a$ from each party. The outcome of this audit is that the private information of both parties becomes public. The collective expenditure of $2 a$ can be regarded as the price of making the private information verifiable. Should litigation occur the bonus payment will only be made if costs were, in fact, high. The idea is that the seller should demand the bonus only when justified, that is, when costs are high. This is, of course, not verifiable unless litigation occurs.

The partial tree illustrated in Figure 1 describes that part of the game corresponding to state $\left(v_{1}, r_{j}, c_{k}\right)$.

Figure 1

The Partial Game Tree

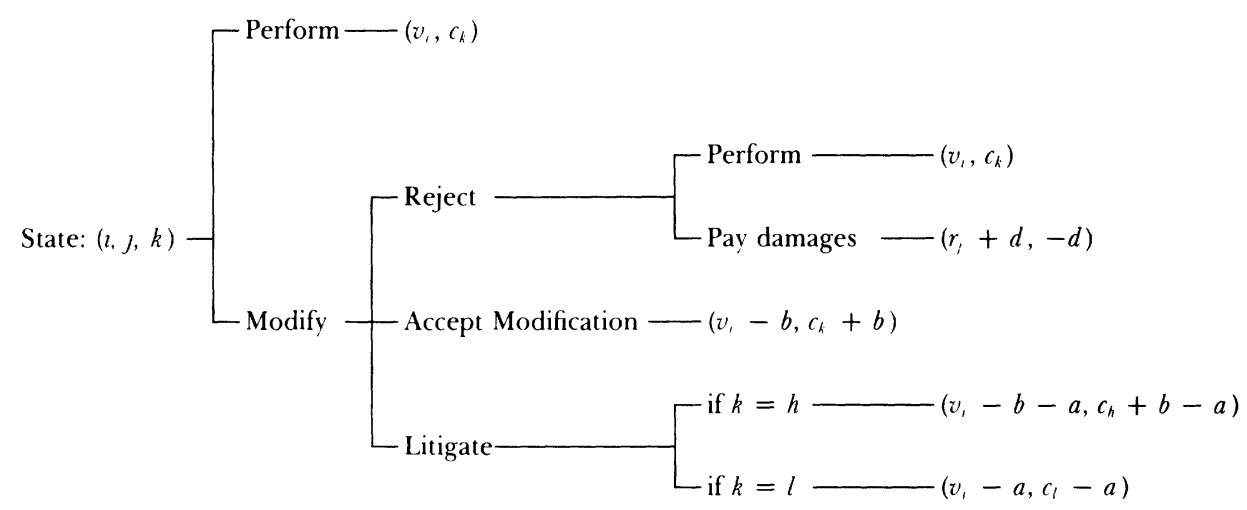

The parties to this situation realize that the initial choice of the contract terms for damages, $d$, and bonus, $b$, define the game that they will subsequently play. Since each can expect no more than the equilibrium payoff 
in this game and since the price of the contract is a remaining term which can be used to redistribute the sum of these expected gains in any way the parties wish, we may regard the players as having substantially the same interests as regards the choice of $d$ and $b$ : making the expected joint payoff from the resulting game as large as possible.

Given these terms, the seller who learns that costs are $c_{k}, k=l, h$ must choose a probability $\mu_{k}$ of modifying (demanding the bonus) and an associated probability $\left(1-\mu_{k}\right)$ of performing without modification. The buyer, in turn, who learns that value and reliance loss are $\left(v_{i}, r_{j}\right) i, j=l, h$ and that the seller wishes to modify must choose a probability of rejecting the modification, $\rho_{i j}$, a probability of accepting the modification, $\alpha_{i j}$, and an associated probability of litigating $\lambda_{i j}=1-\rho_{i j}-\alpha_{i j}$.

The relevance of the seller's choice for the buyer is as follows. Since the seller will modify with a probability of

$$
p_{M}=q_{l} \mu_{l}+q_{h} \mu_{h}
$$

it follows that the probability that the seller is bluffing-actually has low costsgiven that the seller asks for a modification is

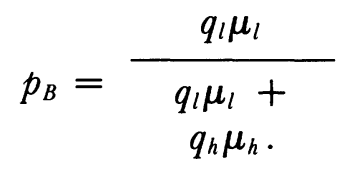

Similarly, the buyer will reject the proposed modification (call) with probability (summing over all possible value and reliance loss states)

$$
p_{R}=\sum \sum p_{i j} \rho_{i j}
$$

will accept the proposed modification (fold) with probability

$$
p_{A}=\sum_{i} p_{i j} \alpha_{i j}
$$

and will litigate (raise) with probability

$$
\begin{aligned}
p_{L} & =\sum \sum p_{i j} \lambda_{i j} \\
& =1-p_{R}-p_{A} .
\end{aligned}
$$

Should the seller modify and the buyer reject, the seller has the remaining choice of whether to perform or not to perform and pay damages $d$. Clearly the seller will choose to perform when $-d<c_{k}$, and not to perform when $-d$ $>c_{k}$, that is, when paying damages is relatively worse. We assume that ties are resolved in the buyer's favor so that if $-d=c_{k}$ (the seller reports he is 
indifferent between performing and paying damages), then the seller will perform if $v_{i}>r_{j}+d$ and not perform if $v_{i}<r_{j}+d$. The payoff to the buyer should the seller modify and the buyer reject is

$$
\theta_{\imath \jmath k} \equiv \begin{cases}\mathrm{v}_{\mathrm{i}} & \text { if }-d<c_{k} \\ \max \left\{v_{i}, r_{j}+d\right\} & \text { if }-d=c_{k} \\ r_{\jmath}+d & \text { if }-d>c_{k} .\end{cases}
$$

The result of these strategy choices is that the buyer who finds himself in state $\left(v_{i}, r_{j}\right)$ will receive an expected payoff of

$$
\Pi_{\imath \jmath}^{B}=p_{M}\left\{\rho_{\imath \jmath} R_{i j}+\alpha_{i j} A_{i j}+\lambda_{i j} L_{i j}\right\}+\left(1-p_{M}\right) v_{i}
$$

where

$$
\begin{aligned}
& R_{i j} \equiv p_{B} \theta_{i j l}+\left(1-p_{B}\right) \theta_{i j h} \\
& A_{i j} \equiv v_{i}-b \\
& L_{i j} \equiv p_{B}\left(v_{i}-a\right)+\left(1-p_{B}\right)\left(v_{i}-b-a\right) .
\end{aligned}
$$

In the expression $\Pi_{i j}^{B}, R_{\imath}$ represents the buyer's expected payoff should the seller modify and the buyer reject, $A_{i}$ should the seller modify and the buyer accept, and $L_{i}$ should the seller modify and the buyer litigate. The $V_{i}$, term represents the buyer's payoff should the seller perform without modification. Each of these four terms is multiplied by its probability to determine the total expected payoff to the buyer.

Similarly, the seller who finds himself in state $c_{k}$ will receive an expected payoff of

$$
\Pi_{k}^{S}=\mu_{k} M_{k}+\left(1-\mu_{k}\right) c_{k}
$$

where

$$
\begin{aligned}
& M_{l} \equiv p_{R} \max \left\{-d, c_{l}\right\}+p_{A}\left(\mathrm{c}_{l}+b\right)+p_{L}\left(c_{l}-a\right) \\
& M_{h} \equiv p_{R} \max \left\{-d, c_{h}\right\}+p_{A}\left(c_{h}+b\right)+p_{L}\left(c_{h}+b-a\right) .
\end{aligned}
$$

In the expression $\Pi_{k}^{S}, M_{k}$ represents the seller's expected payoff should he modify, and $c_{k}$ should he perform without modification.

Since, given $(b, d)$, each party will choose probabilities to maximize his own expected payoff given the probabilities chosen by the other party, we have the following conditions for the seller's choice of probabilities to modify:

$$
\begin{aligned}
& M_{l}>c_{l} \Rightarrow \mu_{l}=1 \\
& M_{l}=c_{l} \Rightarrow 0 \leq \mu_{l} \leq 1 \\
& M_{l}<c_{l} \Rightarrow \mu_{l}=0 .
\end{aligned}
$$




$$
\begin{aligned}
& M_{h}>c_{h} \Rightarrow \mu_{h}=1 \\
& M_{h}=c_{h} \Rightarrow 0 \leq \mu_{h} \leq 1 \\
& M_{h}<c_{h} \Rightarrow \mu_{h}=0 .
\end{aligned}
$$

Together with the following conditions for the buyer's choice of probabilities to reject, accept, or litigate:

$$
\begin{aligned}
& R_{\imath \jmath}>A_{\imath \jmath}, L_{\imath \jmath} \Rightarrow\left\{\begin{array}{l}
\rho_{\imath \jmath}=1 \\
\alpha_{\imath \jmath}=0 \\
\lambda_{i \jmath}=0
\end{array}\right. \\
& A_{i j}>R_{i j}, L_{\imath j} \Rightarrow\left\{\begin{array}{l}
\rho_{\imath \jmath}=0 \\
\alpha_{\imath \jmath}=1 \\
\lambda_{\imath \jmath}=0
\end{array}\right. \\
& L_{\imath \jmath}>A_{\imath \jmath}, R_{\imath \jmath} \Rightarrow\left\{\begin{array}{l}
\rho_{\imath \jmath}=0 \\
\alpha_{\imath \jmath}=0 \\
\lambda_{\imath \jmath}=1
\end{array}\right. \\
& R_{i j}=A_{\imath \jmath}>L_{\imath \jmath} \Rightarrow\left\{\begin{array}{l}
\rho_{\imath \jmath}+\alpha_{\imath \jmath}=1 \\
\lambda_{\imath \jmath}=0
\end{array}\right. \\
& R_{i \jmath}=L_{\imath \jmath}>A_{\imath \jmath} \Rightarrow\left\{\begin{array}{l}
\rho_{\imath \jmath}+\lambda_{i \jmath}=1 \\
\alpha_{\imath \jmath}=0
\end{array}\right. \\
& A_{i j}=L_{i \jmath}>R_{i \jmath} \Rightarrow\left\{\begin{array}{l}
\rho_{i \jmath}=0 \\
\alpha_{i j}+\lambda_{i \jmath}=1
\end{array}\right. \\
& R_{i j}=A_{i j}=L_{i j} \Rightarrow \rho_{i j}+\alpha_{i \jmath}+\lambda_{i j}=1 \text {. }
\end{aligned}
$$

We may now explore the consequences of particular choices for the terms $(d, b)$. To provide for an interesting range of possibilities, suppose that the states in which performance is efficient are

$$
P=\{(l, h, l),(h, l, l),(h, h, l),(h, h, h)\}
$$

so that it is never efficient to perform when both value and reliance are low, and it is only efficient to perform when costs are high if both value and reliance are high. In this setting, a natural candidate is the marginal cost pricing contract

$$
(d, b)=\left(-c_{l},-c_{h}+c_{l}\right)
$$

which is analogous to the "only the buyer's information is private" option contract discussed above.

Since $c_{l}=-d$ and $c_{h}=-b-d$, the fact that $v_{l}+c_{k}<r$ for $(i, j, k) \notin P$ can be expressed as

$$
\begin{gathered}
v_{l}<r_{l}+d \text { for }(i, j, k)=(l, l, l) \text { or }(l, l, h) \\
v_{l}-b<r_{h}+d \text { for }(i, j, k)=(l, h, h) \\
v_{h}-b<r_{l}+d \text { for }(i, j, k)=(h, l, h) .
\end{gathered}
$$

It follows from the first inequality that $R_{l l}=r_{l}+d>v_{l}>A_{l l} L_{l l}$ or that $\rho_{l l}=1$ and $\alpha_{l l}=\lambda_{l l}=0$. It follows from the second that 


$$
\begin{aligned}
\left(R_{l h}\right) & =p_{B} v_{l}+\left(1-p_{B}\right)\left(r_{h}+d\right) \\
& >p_{B}\left(v_{l}-a\right)+\left(1-p_{B}\right)\left(v_{l}-b-a\right)=L_{l h} \\
& >v_{l}-b=A_{l h} .
\end{aligned}
$$

Thus, $\rho_{l h}=\rho_{h l}=1, \alpha_{l h}=\alpha_{h l}=0$, and $\lambda_{l h}=\lambda_{h l}=0$. The buyer rejects modifications unless both valuation and reliance are high. Notice that this choice is independent of the seller's and is thus a dominant strategy.

Since $b-a=-c_{h}+c_{l}-a>0$, it follows that $c_{h}+b-a>c_{h}$. Also, since $-d=c_{l}>c_{h}$, we have $M_{h}>c_{h}$ and thus $\mu_{h}=1$. The seller will always request the modification when costs are high. This result is also independent of the buyer's choice and thus also a dominant strategy.

It remains necessary to consider the choices of the low-cost seller and the high-valuation, high-reliance buyer-the most likely setting for the hold-up game. If equilibrium entails a mixed strategy in which ${ }_{l}>0$ then $M_{l}=c_{l}$ or $P_{L}\left(C_{l}-a\right)=P_{A}\left(C_{l}-b\right)$ or

$$
p_{L} a=p_{A} b
$$

which requires, if $p_{L}, p_{A}>0$, that $A_{h h}=L_{h h} \geq R_{h h}$ or that $p_{B}=a / b$. This solution is illustrated in Figure 2.

FIGURE 2

The Hold-up Game

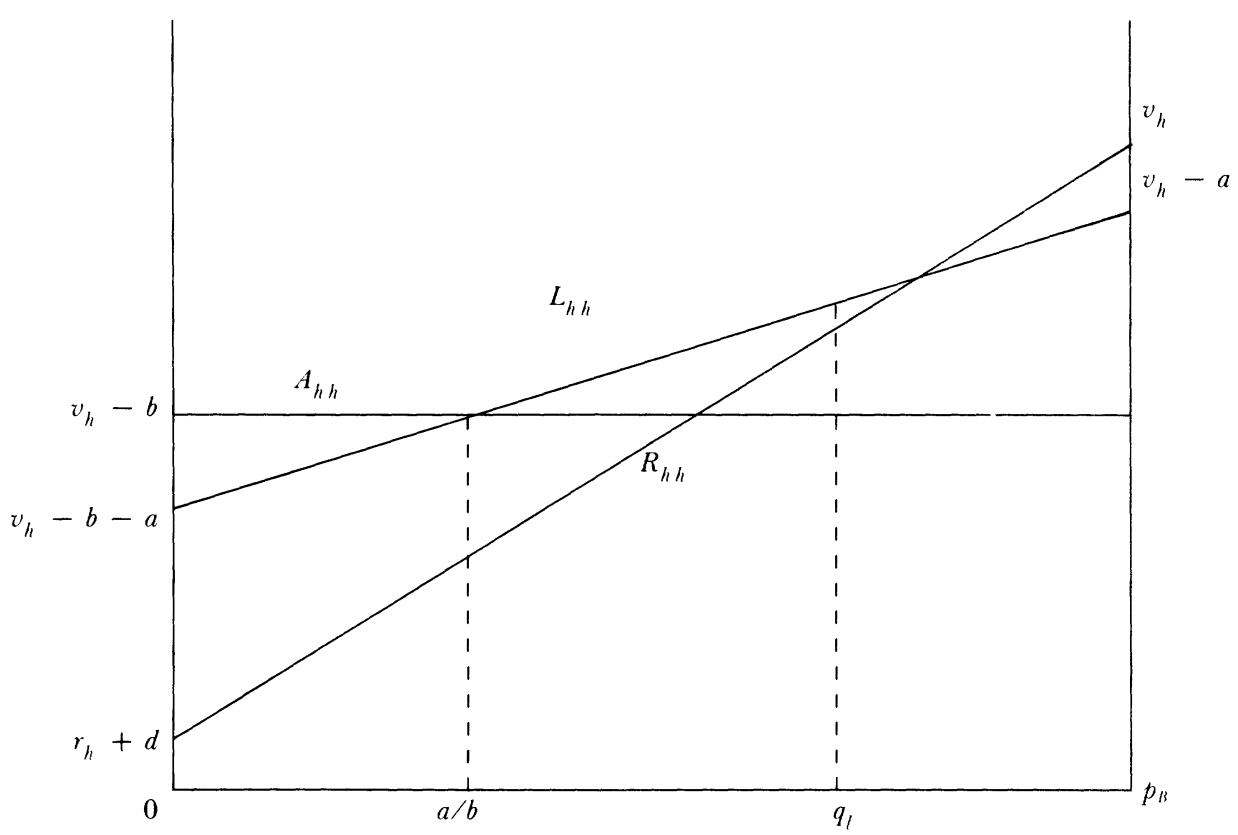

In this graph $p_{B} \leq q_{l}$ is plotted on the horizontal axis and $R_{h h}, A_{h h}$ and $L_{h h}$ on the vertical axis. This graph incorporates several features suggestive of the hold-up game:

(1) A relatively high probability of low costs $q_{l}$; 
(2) A relatively small cost of litigating $a$;

(3) A relatively large "high reliance" cost so that $r_{h}+d$ is small relative to $v_{h}-b$ and $v_{h}-b-a$. In these circumstances the equilibrium is given by

$$
\begin{aligned}
\mu_{l} & =\frac{a q_{h}}{(b-a) q_{l}} \\
\rho_{h h} & =0 \\
\alpha_{h h} & =\frac{a}{a+b} \\
\lambda_{h h} & =\frac{b}{a+b .}
\end{aligned}
$$

This equilibrium is interesting for a variety of reasons. Note to begin with that performance occurs in state $(i, j, k)$ if and only if $(i, j, k) \in P$ - the contract thus induces efficient performance. The only departure from a full information Pareto efficient outcome, in fact, is the expected cost of litigation. This outcome is predicated upon rules for the game which mirror the law in not enforcing modifications based upon duress, that is, an empty threat to take an action which would not, in fact, be advantageous to the person making the threat. The equilibrium also involves mixed strategies consistent with the stylized facts mentioned earlier in which the probability of bluffing is neither zero nor one and the probability of litigating is neither zero nor one. Last, the equilibrium suggests the following answers to the two major questions posed by the hold-up game:

(1) Why are available remedies inadequate as a protection against the hold-up game? The use of a sufficiently larger damages term, $d$ (a more adequate remedy), would affect the equilibrium by making rejection a better alternative for the high value, high reliance buyer than litigation. However, the use of such a large damage term also induces inefficient performance. It is thus possible that the parties themselves would not find it in their interest to choose a large enough damage term to preclude the hold-up game. A modification of the basic game is also possible in which the buyer would decide whether to accept the goods being offered by the seller or to demand a modification. This game would only reverse the roles of potential robber and victim, and expose the seller to a hold-up game in which the buyer sometimes falsely claims to be other than a high value, high reliance type in order to extract cost-concessions from the seller. Here again it is possible that the parties would not find it advantageous to set a large enough liquidated damages term to preclude this reversed hold-up game again because of the incentives 
for inefficient performance. Liquidated damages thus cannot be relied upon as a solution for the hold-up game.

(2) Is there an economic justification for a "fairness" test? The specification of the game places a limit on the modification that can be obtained-the seller can either ask for $b$ or nothing. A small, ex ante increase in $b$ would have the following effect upon the solution. As can be seen in Figure 2, both $A_{h h}$ and the left-hand vertical intercept of $L_{h h}$ shift downward by an amount equal to the increase in $b$. Provided the change in $b$ is small enough, the intersection of $L_{h h}$ and $A_{h h}$ will remain above $R_{h h}$ which has not shifted. This is true for $b$ $\leq \bar{b}$ where $\bar{b}$ is the solution to:

$$
\bar{b}\left(r_{h}+d\right)+a\left(v_{h}-r_{h}-d\right)=\bar{b}\left(v_{h}-\bar{b}\right) .
$$

This increase in $b$ reduces $\rho_{B}, \rho_{l}$, and $\alpha_{h h}$ and increases $\lambda_{h h}$. The unconditional expected payoff to the buyer falls since $\Pi_{\imath j}^{B}$ is unchanged for $(i, j) \neq(h, h)$ and

$$
\Pi_{h h}^{B}=\left(v_{h}-b\right) .
$$

The unconditional expected payoff to the seller increases, however, since $\Pi_{l}^{S}$ is unchanged and

$$
\begin{aligned}
\Pi_{h}^{S} & =-p_{R} d+\left(1-p_{R}\right)\left(c_{h}+b\right)-p_{L} a \\
& =-\left(1-p_{h h}\right) d+p_{h h}\left(c_{h}+b\right)-p_{h h} \frac{b}{a+b} a \\
& =-\left(1-p_{h h}\right) d+p_{h h}\left[c_{h}+\frac{b^{2}}{a+b}\right]
\end{aligned}
$$

Routine calculation shows, moreover,

$$
\begin{aligned}
\frac{\partial\left(q_{h} \Pi_{h}^{S}+p_{h h} \Pi_{h h}^{B}\right)}{\partial b} & =-p_{h h} \frac{\left(1-q_{h}\right) b^{2}+2 a b\left(1-q_{h}\right)+a^{2}}{(a+b)^{2}} \\
& <0
\end{aligned}
$$

Thus, the joint payoff falls with an increase in $b$-a consequence of the increased likelihood of litigation. While it is inefficient to ask for a high $b$, the seller has every incentive to do so since only high valuation, high reliance buyers will accept the cost based modification in any event and such a buyer would be willing in fact to pay as much as $\bar{b}$. Since the buyer loses more than the seller gains there would be a basis for an exchange in which the buyer promises not to ask for more-if this were possible. If it is not possible to make such a promise believable, there is certainly scope for the law to provide such a limitation ex ante in the form of a fairness test. 


\section{VII}

\section{Conclusion}

Our simple game-theoretic model has provided suggestive answers to the major questions involving the hold-up games. A policy of refusing to enforce modifications based upon empty threats was shown to be consistent with the attainment of efficiency and not an impediment to bargaining over modifications. Remedies were shown to be an inadequate protection from the hold-up game because of the fact that damages large enough to prevent the hold-up games may simply be too expensive in terms of the incentives they provide for inefficient performance. Lastly, it was shown that a fairness test could be given an objective economic justification as a limitation upon subsequent modifications which would be regarded as mutually advantageous by the parties themselves at the time of initial contracting. Viewed in this light, the fairness test can be interpreted as providing those terms for the original contract that would have been advantageous to both parties at the time of initial contracting. 